\title{
Nutrient limitation as a strategy for increasing starch accumulation in microalgae
}

\author{
Giuliano Dragone*, Bruno D. Fernandes, Ana P. Abreu, António A. Vicente, José A. Teixeira \\ IBB - Institute for Biotechnology and Bioengineering, Centre of Biological Engineering, University of Minho, Campus de Gualtar. 4710-057, Braga, Portugal
}

\section{A R T I C L E I N F O}

\section{Article history:}

Received 14 December 2010

Received in revised form 10 February 2011

Accepted 13 March 2011

Available online 5 April 2011

\section{Keywords:}

Bioethanol

Biofuel

Chlorella vulgaris

Microalgae

Starch

\begin{abstract}
A B S T R A C T
Increasing microalgal starch content by nutrient limitation has been regarded as an affordable approach for the production of third generation bioethanol. This work evaluated starch accumulation in Chlorella vulgaris P12 under different initial concentrations of nitrogen (0-2.2 $\mathrm{g} \mathrm{urea} \mathrm{L}^{-1}$ ) and iron (0-

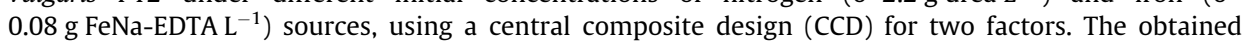
model: Starch content $(\%)=8.220-16.133 X_{1}+13.850 X_{1}^{2}$, relating starch accumulation in microalgae with the coded level for initial urea concentration in the growth medium $\left(X_{1}\right)$ presented a good concordance between the predicted and experimental values $\left(R^{2}=0.94\right)$. Since accumulation of starch occurred at nitrogen depletion conditions under which the cell growth was much slower than that observed during nitrogen supplemented cultivations, a two-stage cultivation process for high starch accumulation $(>40 \%)$ and cell growth of $C$. vulgaris was proposed: a first cultivation stage using nitrogen- and iron-supplemented medium (initial urea and FeNa-EDTA concentrations of 1.1 and $0.08 \mathrm{~g} \mathrm{~L}^{-1}$, respectively), followed by a second cultivation stage in a nitrogen- and iron-free medium. The high starch content obtained suggests C. vulgaris P12 as a very promising feedstock for bioethanol production.
\end{abstract}

(c) 2011 Elsevier Ltd. All rights reserved.

\section{Introduction}

The reliance of the global economy on fossil-derived fuels, coupled with the increasing energy demand in emerging countries (e.g. India and China) and the geo-political instability in some world's oil-producing regions, have led to soaring petroleum prices in the last years. Increased use of fossil fuels will also increase atmospheric carbon dioxide $\left(\mathrm{CO}_{2}\right)$, hastening the global warming crisis. Thus, there is an urgent need to develop sustainable and affordable energy from renewable resources [1]. In this regard, bioethanol from agricultural crops (first generation biofuel system) is a renewable fuel that is attracting the most attention [2]. However, this production system presents significant environmental and economic restraints. The increasing competition with agriculture for cultivable land used for food production has been considered one of the most common concerns related to current first generation biofuels $[3,4]$.

Nowadays, microalgae are considered as one of the most promissory renewable feedstock for biofuels production because of several advantages, such as: faster growth, higher photosynthetic efficiency and biomass production compared to other energy crops [5-8]. The microalga Chlorella vulgaris, in particular, has been recognized as a potential feedstock for bioethanol production due to

\footnotetext{
* Corresponding author. Tel.: +351 253604424; fax: +351 253604429.

E-mail addresses: gdragone@deb.uminho.pt, giulianodragone@hotmail.com (G. Dragone).
}

its capacity to accumulate high levels starch (up to $37 \%$ dry weight) [9].

Several studies have demonstrated that alteration in nutrient concentrations can modify the growth and secondary metabolism of microalgae [10,11]. Furthermore, microalgae growth depends not only on an adequate supply of essential macronutrient elements (carbon, nitrogen, phosphorus, silicon) and major ions $\left(\mathrm{Mg}^{2+}, \mathrm{Ca}^{2+}, \mathrm{Cl}^{-}\right.$, and $\left.\mathrm{SO}_{4}^{2-}\right)$ but also on a number of micronutrient metals such as iron, manganese, zinc, cobalt, copper, and molybdenum [12]. Iron is needed for the growth of all phytoplankton. It serves essential metabolic functions in photosynthetic electron transport, respiratory electron transport, nitrate and nitrite reduction, sulphate reduction, dinitrogen $\left(\mathrm{N}_{2}\right)$ fixation, and detoxification of reactive oxygen species (e.g., superoxide radicals and hydrogen peroxide) [13].

Although numerous reports have shown that cell composition of microalgae can be affected by a single chemical or physical factor, the effectiveness of such treatment is usually poor, and the change is slow [14]. In fermentation processes, where several variables have to be simultaneously contemplated, it is necessary that the optimization method take their interactions in consideration [15]. The statistical optimization technique through factorial design and response surface analysis satisfy this requirement. The use of factorial design is advantageous as it allows to obtain maximum information of the process by performing a reduced number of experiments [16]. In this sense, central composite design (CCD), a useful methodology that is employed for sequential experimentation, provides reasonable amount of information for testing the 
goodness of fit from a fewer number of assays, therefore reducing the overall cost associated with the analysis [17]. CCD are $2 k$ factorial treatment designs with $2 k$ additional treatment combinations called axial points and $n_{0}$ replications at the center of design. The property of rotatability developed for $C C D$ requires the variance of estimated values to be constant at points equally distant from the center of design [18]. Thus, our study evaluated the effect of initial concentrations of nitrogen and iron sources on starch accumulation in C. vulgaris using a central composite design (CCD) for two factors. Starch productivity and cell growth were also considered for optimization of the culture medium.

\section{Material and methods}

\subsection{Microorganism and culture conditions}

C. vulgaris (P12) obtained from the Culture Collection of Algal Laboratory (CCALA, Czech Republic), was used for cultivation. All culture experiments were performed at $30{ }^{\circ} \mathrm{C}$ in $50 \mathrm{~mL}$ glass bubble columns photobioreactors containing $40 \mathrm{~mL}$ of medium. The carbon source and agitation during cultivation of microalgae were supplied by bubbling $\mathrm{CO}_{2}$-enriched air $\left(2 \% \mathrm{v} / \mathrm{v} \mathrm{CO}_{2}\right)$ through a tube (inner diameter, $2 \mathrm{~mm}$ ) that ended near the bottom of the column, at an aeration rate of $0.833 \mathrm{vvm}$ (volume of gases per volume of culture suspension per minute). Illumination was provided by four fluorescent lamps (Sylvania Standard F18 W) on one side of the photobioreactos, at an irradiance level of $70 \mu \mathrm{mol} \mathrm{m} \mathrm{m}^{-2} \mathrm{~s}^{-1}$. The original growth medium (OGM) based on chemical components present in the microalgal biomass [19] had the following composition (mM): $18.32\left(\mathrm{NH}_{2}\right)_{2} \mathrm{CO}, 1.74 \mathrm{KH}_{2} \mathrm{PO}_{4}, 0.83 \mathrm{MgSO}_{4} \cdot 7 \mathrm{H}_{2} \mathrm{O}, 0.79 \mathrm{CaCl}_{2}$, 0.11 FeNa- $\mathrm{C}_{10} \mathrm{H}_{12} \mathrm{O}_{8} \mathrm{~N}_{2}, 0.017 \mathrm{MnCl}_{2} \cdot 4 \mathrm{H}_{2} \mathrm{O}, 0.013 \mathrm{H}_{3} \mathrm{BO}_{3}, 0.009$ $\mathrm{ZnSO}_{4} \cdot 7 \mathrm{H}_{2} \mathrm{O}, \quad 0.004 \quad \mathrm{CuSO}_{4} \cdot 5 \mathrm{H}_{2} \mathrm{O}, \quad 0.002 \quad \mathrm{CoSO}_{4} \cdot 7 \mathrm{H}_{2} \mathrm{O}, \quad 0.0001$ $\left(\mathrm{NH}_{4}\right)_{6} \mathrm{Mo}_{7} \mathrm{O}_{24} \cdot 4 \mathrm{H}_{2} \mathrm{O}$ and $0.0001\left(\mathrm{NH}_{4}\right) \mathrm{VO}_{3}$ in distilled water.

Prior to the main experiments, microalgae were cultivated in the OGM to the late-exponential growth phase, then centrifuged at $6000 \mathrm{rpm}$ for $15 \mathrm{~min}$, washed in distilled $\mathrm{H}_{2} \mathrm{O}$ and re-suspended in culture medium with a nutrient composition defined by the experimental design. The starting algal density was the same in all experiments of the central composite design: $2 \times 10^{7}$ cells $\mathrm{mL}^{-1}$.

\subsection{Biomass concentration}

Microalgae and culture medium were withdrawn from the photobioreactors throughout the assay. Microalgal density was measured microscopically using an improved Neubauer hemocytometer. The growth rate of microalgae was also measured by cell dry weight. Microalgae were also harvested by centrifugation at $6000 \mathrm{rpm}$ during $15 \mathrm{~min}$, washed with distilled $\mathrm{H}_{2} \mathrm{O}$, and dried at $105^{\circ} \mathrm{C}$ until constant weight $(24 \mathrm{~h})$.

\subsection{Starch determination}

The concentration of microalgal starch at the beginning of the stationary growth phase was assayed by the hydrolysis of starch to glucose with amylolytic enzymes ( $\alpha$-amylase and amyloglucosidase) according to the procedure provided by Megazyme (Wicklow, Ireland) and accepted by AOAC (Official Method 996.11) and AACC (Method 76.13). Lyophilized microalgae biomass was disintegrated with a mortar and pestle, re-suspended in aqueous ethanol and incubated in a water bath at $80-85^{\circ} \mathrm{C}$ for $5 \mathrm{~min}$, to extract the pigments. Thermostable $\alpha$-amylase $\left(3000 \mathrm{U} \mathrm{mL}^{-1}\right)$ in MOPS buffer $(50 \mathrm{mM}, \mathrm{pH} 7.0)$ including $5 \mathrm{mM} \mathrm{CaCl}_{2}$, was added to each sample. The samples were maintained at $100{ }^{\circ} \mathrm{C}$ during $6 \mathrm{~min}$, followed by heating at $50^{\circ} \mathrm{C}$. Amyloglucosidase
(3300 $\mathrm{U} \mathrm{mL}^{-1}$ ) in sodium acetate buffer was then added to each sample. Samples were subsequently maintained at $50{ }^{\circ} \mathrm{C}$ for $30 \mathrm{~min}$, and then centrifuged $(10 \mathrm{~min})$ at $3000 \mathrm{rpm}$. Glucose in the supernatant was assessed by glucose oxidase method.

Total starch content was determined by multiplying the percentage of microalgal starch with the corresponding biomass concentration. The productivity of starch was calculated by the equation below:

$P_{\text {Starch }}\left(\mathrm{g} \mathrm{L}^{-1}\right.$ day $\left.^{-1}\right)=\left(C_{\text {Starch }}(\%) \times W\left(\mathrm{~g} \mathrm{~L}^{-1}\right)\right) / T$ (day)

where $P_{\text {Starch }}$ is the starch productivity, $C_{\text {Starch }}$ is the percentage of microalgal starch, $W$ is the dry weight of microalgae, and $T$ is the time of cultivation.

\subsection{Statistical analysis of the design of experiments (DoE)}

The influence of the initial concentration of nitrogen and iron sources (independent variables) on starch content (dependent variable) in C. vulgaris was assessed through a full central composite design (CCD) for two factors. The coding used for these variables is shown in Eq. (2).

$v_{i}=\left(V_{i}-V_{0}\right) / \Delta V_{i}$

where $v_{i}$ is the coded variable, $V_{i}$ is the real value, $V_{0}$ is the real value at the central point and $\Delta V_{i}$ the step change value.

Table 1 presents the range of real and coded values of the independent variables used in this study.

The experimental results were fitted with a second-order polynomial equation by multiple regression analysis. The quadratic mode for predicting the optimal point was expressed according to Eq. (3), where $\hat{y}_{i}$ represents the response variable, $b_{0}$ is the interception coefficient, $b_{i}, b_{i i}$ and $b_{i j}$ are the regression coefficients, $n$ is the number of studied variables, and $X_{i}$ and $X_{j}$ represent the independent variables. Where possible, the model was simplified by elimination of statistically insignificant terms.

$\hat{y}_{i}=b_{0}+\sum_{i=1}^{n} b_{i} X_{i}+\sum_{i=1}^{n} b_{i i} X_{i}^{2}+\sum_{i=1}^{n-1} \sum_{j=i+1}^{n} b_{i j} X_{i} X_{j}$

The quality of the fitted polynomial model was expressed by the coefficient of determination $R^{2}$, and its statistical significance was checked by the $F$-test. The significance of the regression coefficients was tested by $t$-value. The statistical analysis of the results was carried out with the Experimental Design Module of the software Statistica 8.0 (Statsoft, USA). The model permitted evaluation of the effects of linear, quadratic and interactive terms of the independent variables on the chosen dependent variables.

\section{Results and discussion}

\subsection{Starch accumulation in C. vulgaris strain P12}

The experimental results obtained by the cultivation of $C$. vulgaris under different nutritional conditions based on the CCD for two factors, are shown in Table 2 . It can be noted that $C$. vulgaris was able to accumulate starch under all the evaluated conditions; however, the amount of starch produced strongly varied according to the levels employed for the independent variables. The highest starch contents $(41.0 \%, 40.5 \%$ and $39.8 \%)$ were obtained under nitrogen-deprived conditions (initial urea concentration $=0 \mathrm{~g} \mathrm{~L}^{-1}$ ) and initial FeNa-EDTA concentrations of $0.04,0$ and $0.08 \mathrm{~g} \mathrm{~L}^{-1}$, respectively (Runs 5,1 and 2 ).

The results obtained in our study were remarkable when compared with previously reported data, some of which are summarized in Table 3. As shown in this table, the microalgal starch content obtained in this study $(41.0 \%)$ was the highest in 
Table 1

Levels and range of the independent variables (initial concentration of nitrogen and iron sources) based on the full CCD for two factors.

\begin{tabular}{lllll}
\hline Independent variable & Symbol & \multicolumn{3}{l}{$\begin{array}{l}\text { Levels and Range } \\
\left(\mathrm{g} \mathrm{L}^{-1}\right)\end{array}$} \\
\cline { 2 - 5 } & & -1 & 0 & +1 \\
\hline Initial nitrogen source (urea) concentration & $X_{1}$ & 0 & 1.1 & 2.2 \\
Initial iron source (FeNa-EDTA) concentration & $X_{2}$ & 0 & 0.04 & 0.08 \\
\hline
\end{tabular}

Table 2

Experimental matrix and results of microalgal starch accumulation (\%) with coded levels of initial urea concentration $\left(X_{1}\right)$ and initial FeNa-EDTA concentration $\left(X_{2}\right)$ according to the full CCD.

\begin{tabular}{rlllll}
\hline \multirow{2}{*}{ Assays } & \multicolumn{2}{l}{ Independent variables } & & \multicolumn{2}{c}{ Starch content $(\%)$} \\
\cline { 2 - 3 } \cline { 5 - 6 } & $X_{1}$ & $X_{2}$ & & Experimental & Predicted \\
\hline 1 & -1 & -1 & 40.5 & 38.2 \\
2 & -1 & +1 & 39.8 & 38.2 \\
3 & +1 & -1 & 9.9 & 5.9 \\
4 & +1 & +1 & 3.2 & 5.9 \\
5 & -1 & 0 & 41.0 & 38.2 \\
6 & +1 & 0 & 11.5 & 5.9 \\
7 & 0 & -1 & 23.0 & 8.2 \\
8 & 0 & +1 & 8.4 & 8.2 \\
9 & 0 & 0 & 4.8 & 8.2 \\
10 & 0 & 0 & 5.6 & 8.2 \\
11 & 0 & 0 & 5.9 & 8.2 \\
\hline
\end{tabular}

comparison with those values reported in the literature resulting from the photoautotrophic cultivation of other $C$. vulgaris species. This content of starch in C. vulgaris P12 was almost the double of the starch yield found in Chlorella sp. TISTR 8485 and Chlorella sp. TISTR 8593 [20]. It is worth mentioning that higher starch accumulations than those attained in our work were already reported by Hirano et al. [9] and Choi et al. [22] during the cultivation of Chlamydomonas reinhardtii species. However, the higher light intensity used for those experiments in comparison with that employed in our study could explain such differences (Table 3). High light intensities tend to enhance the production of polysaccharides in microalgae. Friedman et al. [23] demonstrated that 0.6- and 3fold increases in polysaccharide content were obtained in cultures of Porphyridium sp. and Porphyridium aerugineum, respectively, when the growth light intensity was raised from 75 to $300 \mu \mathrm{E} \mathrm{m}^{-2} \mathrm{~s}^{-1}$. Tredici et al. [24] reported that carbohydrate synthesis in Spirulina platensis grown outdoors was significantly higher on sunny days than on cloudy days.

Due to the large differences observed in the amount of starch produced by $C$. vulgaris strain P12, a statistical analysis was carried out aiming at identifying which independent variable had significant influence on starch accumulation. The statistical significance of the initial nitrogen and iron sources on the response variable (starch content) is given in Table 4. According to this analysis, the initial urea concentration was the only variable with significant influence on starch content at 95\% confidence level. Such effect was negative, indicating that the starch content was enhanced by decreasing the initial concentration of the nitrogen source. This result ratifies previous findings of Behrens et al. [25], where starch accumulation in C. vulgaris increased under nitrogen-starved conditions. The possible reason could be that under nitrogen deficiency/limitations the available nitrogen is utilized for synthesis of enzymes and essential cell structures. Any carbon dioxide subsequently fixed is therefore converted into carbohydrate or lipid rather than protein $[26,27]$.

The initial iron source concentration did not present a statistically significant effect on starch content, implying that chelated
Table 3

Starch content of green microalgal species cultivated under photoautotrophic conditions.

\begin{tabular}{|c|c|c|c|c|}
\hline Microalgal species & $\begin{array}{l}\text { Starch } \\
\text { content } \\
(\%)\end{array}$ & $\begin{array}{l}\text { Illuminance } \\
\text { (lx) }\end{array}$ & 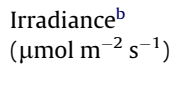 & Refs. \\
\hline Chlorella sp. TISTR 8485 & 21 & - & 60 & $\begin{array}{l}\text { Rodjaroen } \\
\text { et al. [20] }\end{array}$ \\
\hline Chlorella sp. TISTR 8485 & 27 & - & 60 & $\begin{array}{l}\text { Rodjaroen } \\
\text { et al. [20] }\end{array}$ \\
\hline Chlorella sp. TISTR 8593 & 22 & - & 60 & $\begin{array}{l}\text { Rodjaroen } \\
\text { et al. [20] }\end{array}$ \\
\hline $\begin{array}{l}\text { Chlorococcum sp. TISTR } \\
\quad 8583\end{array}$ & 26 & - & 60 & $\begin{array}{l}\text { Rodjaroen } \\
\text { et al. [20] }\end{array}$ \\
\hline $\begin{array}{l}\text { Chlorococcum sp. TISTR } \\
8973\end{array}$ & 17 & - & 60 & $\begin{array}{l}\text { Rodjaroen } \\
\text { et al. [20] }\end{array}$ \\
\hline $\begin{array}{l}\text { Scenedesmus sp. TISTR } \\
\quad 8579\end{array}$ & 20 & - & 60 & $\begin{array}{l}\text { Rodjaroen } \\
\text { et al. [20] }\end{array}$ \\
\hline $\begin{array}{l}\text { Scenedesmus sp. TISTR } \\
\quad 8982\end{array}$ & 13 & - & 60 & $\begin{array}{l}\text { Rodjaroen } \\
\text { et al. [20] }\end{array}$ \\
\hline $\begin{array}{l}\text { S. acuminatus TISTR } \\
8457\end{array}$ & 7 & - & 60 & $\begin{array}{l}\text { Rodjaroen } \\
\text { et al. [20] }\end{array}$ \\
\hline $\begin{array}{l}\text { S. acutiformis TISTR } \\
8495\end{array}$ & 16 & - & 60 & $\begin{array}{l}\text { Rodjaroen } \\
\text { et al. [20] }\end{array}$ \\
\hline S. acutus TISTR 8447 & 19 & - & 60 & $\begin{array}{l}\text { Rodjaroen } \\
\text { et al. [20] }\end{array}$ \\
\hline S. arcuatus TISTR 8587 & 13 & - & 60 & $\begin{array}{l}\text { Rodjaroen } \\
\text { et al. [20] }\end{array}$ \\
\hline S. armatus TISTR 8591 & 15 & - & 60 & $\begin{array}{l}\text { Rodjaroen } \\
\text { et al. [20] }\end{array}$ \\
\hline S. obliquus TISTR 8522 & 24 & - & 60 & $\begin{array}{l}\text { Rodjaroen } \\
\text { et al. [20] }\end{array}$ \\
\hline S. obliquus TISTR 8546 & 23 & - & 60 & $\begin{array}{l}\text { Rodjaroen } \\
\text { et al. [20] }\end{array}$ \\
\hline Nannochlorum sp. Tit-1 & 25 & - & - & $\begin{array}{l}\text { Hon-nami and } \\
\text { Kunito [21] }\end{array}$ \\
\hline $\begin{array}{l}\text { Chlamydomonas sp. YA- } \\
\quad \text { SH-1 }\end{array}$ & $30-39$ & - & - & $\begin{array}{l}\text { Hon-nami and } \\
\text { Kunito [21] }\end{array}$ \\
\hline C. vulgaris IAM C-534 & 37 & 15,000 & - & $\begin{array}{l}\text { Hirano et al. } \\
\text { [9] }\end{array}$ \\
\hline $\begin{array}{c}\text { Chlamydomonas } \\
\text { reinhardtii } \\
\text { UTEX } 2247\end{array}$ & 45 & 15,000 & - & $\begin{array}{l}\text { Hirano et al. } \\
\text { [9] }\end{array}$ \\
\hline $\begin{array}{l}\text { Chlamydomonas } \\
\quad \text { reinhardtii UTEX } 90\end{array}$ & 44 & - & 450 & Choi et al. [22] \\
\hline C. vulgaris $\mathrm{P} 12$ & 41 & - & 70 & This study \\
\hline
\end{tabular}

a Illuminance: the total luminous flux incident on a surface, per unit area.

b Irradiance: the power per unit area of electromagnetic radiation at a surface.

$\mathrm{Fe}(\mathrm{III})$ did not affect the starch accumulation in C. vulgaris. Interaction effects among the studied variables were also not significant at $95 \%$ confidence level.

After identification of the variable affecting the starch accumulation, the experimental values were fitted to a second-order equation (Eq. (4)) obtained by multiple regression analysis. The coefficients of the proposed equation are given below:

Starch content $(\%)=8.220-16.133 X_{1}+13.850 X_{1}^{2}$

$R^{2}=0.94$

where $X_{1}$ represents the coded level for initial urea concentration.

The quality of the quadratic fit, simplified by elimination of statistically insignificant terms, was represented by the coefficient of determination $R^{2}$. As can be noted, the model explains at least $90 \%$ of the dependent variable's variability $\left(R^{2}>0.90\right)$. The high $R^{2}$ means that the quadratic model is able to represent values in the experimental region in an accurate manner. The values predicted by the model are displayed in Table 2 along with the observed values. Comparison of these data indicates that there is a good agreement between the predicted and experimental values for the proposed range. Therefore, the central composite design and 
Table 4

Statistical analysis for starch accumulation in C. vulgaris according to the full CCD for two factors.

\begin{tabular}{lllrl}
\hline $\begin{array}{l}\text { Variables and } \\
\text { interactions }\end{array}$ & $\begin{array}{l}\text { Estimated } \\
\text { effects }\end{array}$ & $\begin{array}{l}\text { Standard } \\
\text { errors }\end{array}$ & $t$-value & $p$ \\
\hline$X_{1}$ & -32.267 & 4.559 & -7.078 & $0.001^{*}$ \\
$X_{1}^{2}$ & 27.700 & 7.016 & 3.948 & $0.011^{*}$ \\
$X_{2}$ & -7.327 & 4.559 & -1.607 & 0.169 \\
$X_{2}^{2}$ & 6.660 & 7.016 & 0.949 & 0.386 \\
$X_{1} X_{2}$ & -3.015 & 5.583 & -0.540 & 0.612 \\
\hline
\end{tabular}

$X_{1}=$ coded values of initial urea concentration; $X_{2}=$ coded values of initial FeNaEDTA concentration.

Significant influence at 95\% confidence level.

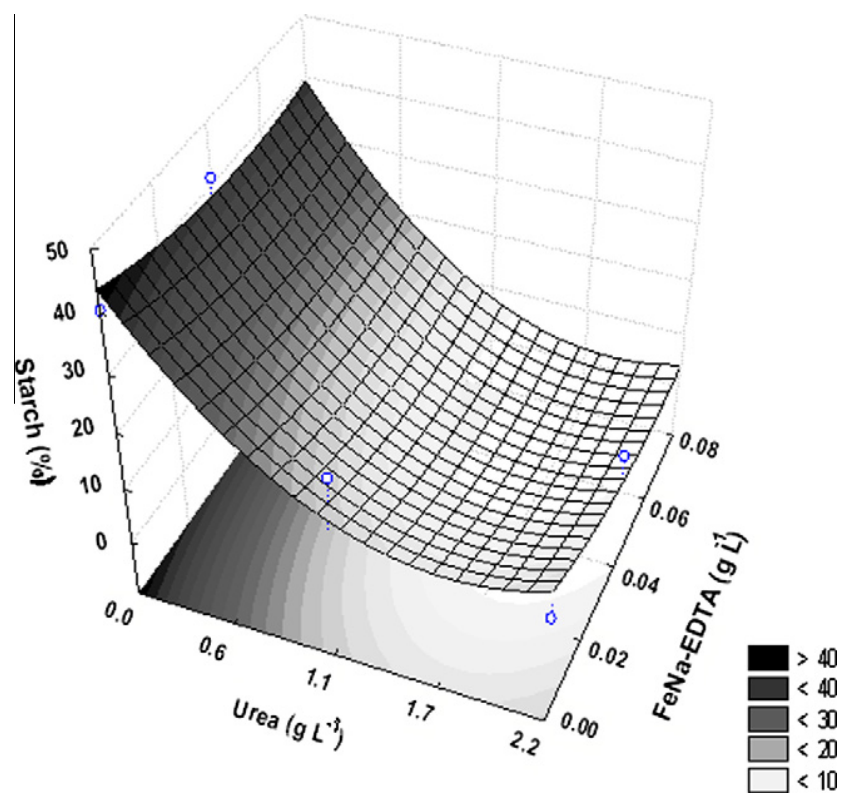

Fig. 1. Response surface of starch accumulation in C. vulgaris as a function of initial urea concentration and initial FeNa-EDTA concentration.

regression analysis were effective in identifying the optimal conditions for maximum accumulation of microalgal starch for the different nutritional conditions.

The relation between independent variables and starch content in C. vulgaris can be best visualized by examining the surface plot presented in Fig. 1.

Fig. 1 clearly shows that decreasing initial urea concentration resulted in higher starch accumulation, with maxima values $(\geqslant 40 \%)$ being achieved under the minimum urea concentration $\left(0 \mathrm{mg} \mathrm{L}^{-1}\right)$. These results implicate that the optimization using a response surface methodology based on the CCD can save the time and effort by the estimation of the variables that significantly influenced the starch accumulation in $C$. vulgaris.

\subsection{Microalgal cell growth}

To explore the influence of the initial nitrogen source concentration and initial chelated $\mathrm{Fe}(\mathrm{III})$ concentration on microalgal cell growth, the conditions of the experimental design which yielded higher starch content in microalgae (values of starch content $>8.4 \%$ ), were considered. The time-course profiles of cell growth obtained with different initial urea concentrations are depicted in Fig. 2.

As shown in Fig. 2a and b, the cell growth of $C$. vulgaris improved significantly when urea concentration increased from 0 to
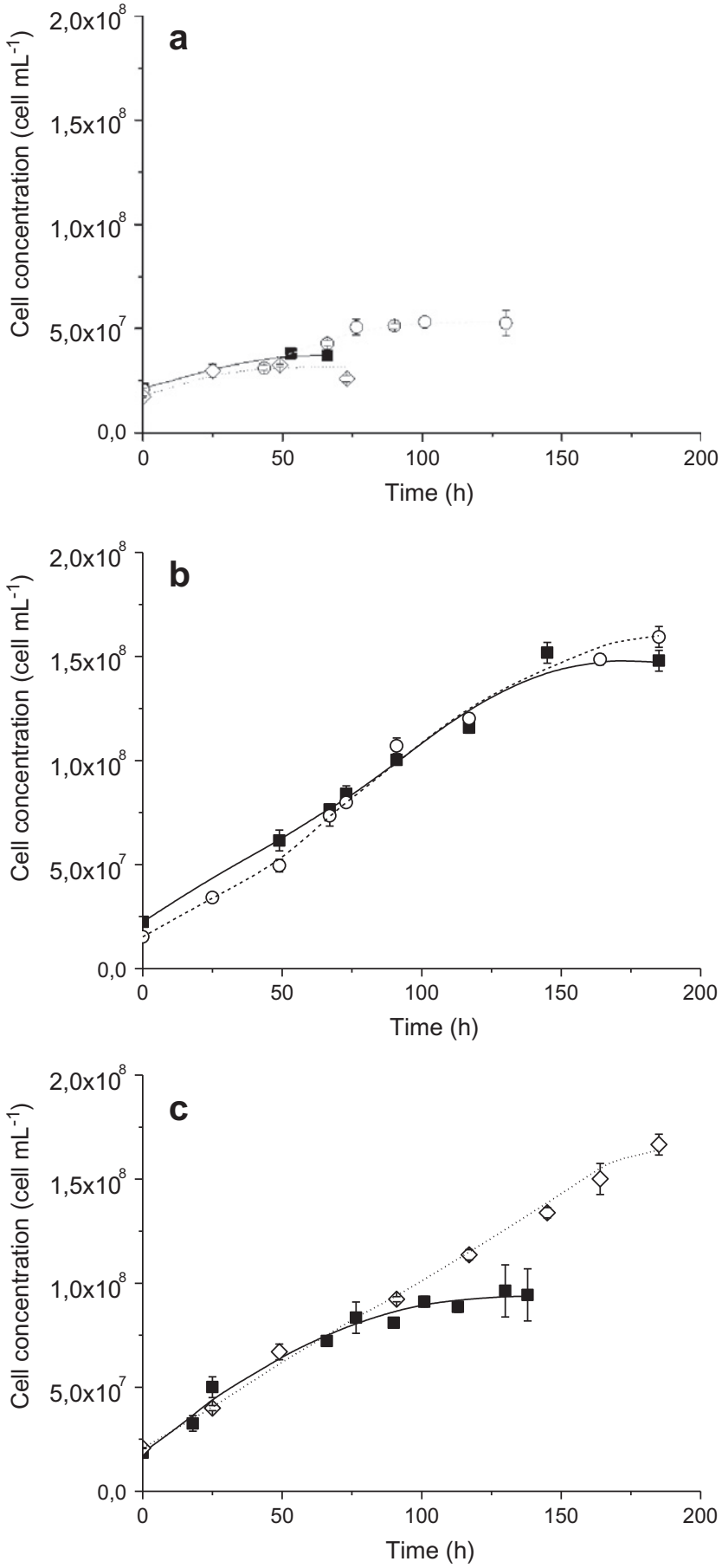

Fig. 2. Cell growth of $C$. vulgaris with different urea concentrations: (a) $0 \mathrm{~g} \mathrm{~L}^{-1}$, (b) $1.1 \mathrm{~g} \mathrm{~L}^{-1}$ and (c) $2.2 \mathrm{~g} \mathrm{~L}^{-1}$. Initial FeNa-EDTA concentration: (口) $0 \mathrm{~g} \mathrm{~L}^{-1},(\diamond)$ $0.04 \mathrm{~g} \mathrm{~L}^{-1}$ and (O) $0.08 \mathrm{~g} \mathrm{~L}^{-1}$.

$1.1 \mathrm{~g} \mathrm{~L}^{-1}(0-18 \mathrm{mM}$, respectively). This result is compatible with previous research observations. For example, Hsieh and $\mathrm{Wu}$ [11] reported that higher initial urea concentration (from 0.025 to $0.200 \mathrm{~g} \mathrm{~L}^{-1}$ ) of the nutrient medium resulted in an increased biomass yield of Chlorella sp. However, cell growth did not show significant difference when urea concentration further increased from 1.1 to $2.2 \mathrm{~g} \mathrm{~L}^{-1}$ (18-37 mM, respectively) (Fig. 2b and c). Cell concentration reached the highest value at 1.1 and $2.2 \mathrm{~g} \mathrm{~L}^{-1}$ initial urea concentration, which was $1.6 \times 10^{8}$ cell $\mathrm{mL}^{-1}$ when initial FeNa-EDTA concentrations were 0.08 and $0.04 \mathrm{~g} \mathrm{~L}^{-1}$, respectively. Although final cell concentration rose from $3.7 \times 10^{7}$ to 
$5.3 \times 10^{7}$ cell $\mathrm{mL}^{-1}$ when the concentration of FeNa-EDTA increased in the range $0-0.08 \mathrm{~g} \mathrm{~L}^{-1}(0-190 \mu \mathrm{M})$ under nitrogen-deprived conditions (initial urea concentration $=0 \mathrm{~g} \mathrm{~L}^{-1}$ ), there was no significant difference among them according to a Tukey's test $(p<0.05)$ (Fig. 2a). On the other hand, growth of microalgae was positively influenced as the initial concentration of the iron source was raised from 0 to $0.04 \mathrm{~g} \mathrm{~L}^{-1}$, maintaining the initial urea concentration at the highest level $\left(2.2 \mathrm{~g} \mathrm{~L}^{-1}\right)$ (Fig. 2c).

The results described above hint that the optimum concentration of urea required for the growth of microalgae was $1.1 \mathrm{~g} \mathrm{~L}^{-1}$, while the lowest concentrations of nitrogen and iron sources led to the highest starch productivity $\left(0.199 \mathrm{~g} \mathrm{~L}^{-1} \mathrm{day}^{-1}\right)$. These data implies that a two-stage cultivation process would likely be optimal for a high starch yield from C. vulgaris strain P12: a first cultivation stage using a $\mathrm{N}$ - and Fe-supplemented medium (initial urea and FeNa-EDTA concentrations of 1.1 and $0.08 \mathrm{~g} \mathrm{~L}^{-1}$, respectively) to attain a maximum growth rate and concentration of biomass, followed by a second stage that involves cell cultivation in a Nand Fe-free medium for a few days.

\section{Conclusions}

In this work, starch content of freshwater microalga C. vulgaris strain P12 reached up to $41.0 \%$ of dry cell weight, which was 8 -fold higher than the control (central points of the experimental design). This result was achieved simply by altering the initial concentrations of urea and FeNa-EDTA in the culture medium. Since accumulation of starch occurred at nitrogen depletion conditions under which the cell growth was much slower than that observed during nitrogen supplemented cultivations, compromising between increasing starch content and cell growth will be necessary in order to attain high values of both biomass concentration and starch productivity.

\section{Acknowledgements}

This research work was supported by the Grants SFRH/BPD/ 44935/2008 (Giuliano Dragone) and SFRH/BD/44724/2008 (Bruno Fernandes) from Fundação para a Ciência e a Tecnologia (Portugal). The authors also acknowledge the financial support received through the projects INNOVALGAE (FCT PTDC/AAC-AMB/108511/ 2008) and ALGANOL.

\section{References}

[1] Khanal SK. Bioenergy generation from residues of biofuel industries. In: Khanal SK, editor. Anaerobic biotechnology for energy production: principles and applications. Iowa: John Wiley \& Sons; 2008. p. 161-88.

[2] Chisti Y. Biodiesel from microalgae beats bioethanol. Trends Biotechnol 2008;26:126-31.

[3] Schenk P, Thomas-Hall S, Stephens E, Marx U, Mussgnug J, Posten C, et al. Second generation biofuels: high-efficiency microalgae for biodiesel production. Bioenergy Res 2008;1:20-43.
[4] Dragone G, Fernandes B, Vicente A, Teixeira JA. Third generation biofuels from microalgae. In: Vilas AM, editor. Current research, technology and education topics in applied microbiology and microbial biotechnology. Badajoz: Formatex Research Center; 2010. p. 1355-66.

[5] Liu Z-Y, Wang G-C, Zhou B-C. Effect of iron on growth and lipid accumulation in Chlorella vulgaris. Bioresour Technol 2008;99:4717-22.

[6] Fernandes B, Dragone G, Teixeira J, Vicente A. Light regime characterization in an airlift photobioreactor for production of microalgae with high starch content. Appl Biochem Biotechnol 2010;161:218-26.

[7] Huang G, Chen F, Wei D, Zhang X, Chen G. Biodiesel production by microalgal biotechnology. Appl Energy 2010;87:38-46.

[8] Amaro HM, Guedes AC, Malcata FX. Advances and perspectives in using microalgae to produce biodiesel. Appl Energy 2011;88(10):3402-10.

[9] Hirano A, Ueda R, Hirayama S, Ogushi Y. $\mathrm{CO}_{2}$ fixation and ethanol production with microalgal photosynthesis and intracellular anaerobic fermentation. Energy 1997;22:137-42.

[10] Behrens PW, Kyle DJ. Microalgae as a source of fatty acids. J Food Lipids 1996;3:259-72.

[11] Hsieh C-H, Wu W-T. Cultivation of microalgae for oil production with a cultivation strategy of urea limitation. Bioresour Technol 2009;100:3921-6.

[12] Sunda WG, Price NM, Morel FMM. Trace metal ion buffers and their use in culture studies. In: Andersen RA, editor. Algal culturing techniques. Amsterdam: Elsevier; 2005. p. 35-63.

[13] Sunda WG, Huntsman SA. Interrelated influence of iron, light and cell size on marine phytoplankton growth. Nature 1997;390:389-92.

[14] Hu Q. Environmental effects on cell composition. In: Richmond A, editor. Handbook of microalgal culture: biotechnology and applied phycology. Oxford: Wiley-Blackwell; 2004. p. 83-93.

[15] Dragone G, Silva DP, e Silva JB, de Almeida Lima U. Improvement of the ethanol productivity in a high gravity brewing at pilot plant scale. Biotechnol Lett 2003;25:1171-4.

[16] Dragone G, Silva DP, e Silva JB. Factors influencing ethanol production rates at high-gravity brewing. Lebensm-Wiss u-Technol 2004;37:797-802.

[17] Sharma S, Malik A, Satya S. Application of response surface methodology (RSM) for optimization of nutrient supplementation for $\mathrm{Cr}(\mathrm{VI})$ removal by Aspergillus lentulus AML05. J Hazard Mater 2009;164:1198-204.

[18] Djoudi W, Aissani-Benissad F, Bourouina-Bacha S. Optimization of copper cementation process by iron using central composite design experiments. Chem Eng J 2007;133:1-6.

[19] Douskova I, Doucha J, Livansky K, Machat J, Novak P, Umysova D, et al. Simultaneous flue gas bioremediation and reduction of microalgal biomass production costs. Appl Microbiol Biotechnol 2009;82:179-85.

[20] Rodjaroen S, Juntawong N, Mahakhant A, Miyamoto K. High biomass production and starch accumulation in native green algal strains and cyanobacterial strains of Thailand. Kasetsart J (Nat Sci) 2007;41:570-5.

[21] Hon-nami K, Kunito S. Microalgae cultivation in a tubular bioreactor and utilization of their cells. Chin J Oceanol Limnol 1998;16:75-83.

[22] Choi SP, Nguyen MT, Sim SJ. Enzymatic pretreatment of Chlamydomonas reinhardtii biomass for ethanol production. Bioresour Technol 2010;101:5330-6.

[23] Friedman O, Dubinsky Z, Arad S. Effect of light intensity on growth and polysaccharide production in red and blue-green rhodophyta unicells. Bioresour Technol 1991;38:105-10.

[24] Tredici MR, Carlozzi P, Chini Zittelli G, Materassi R. A vertical alveolar panel (VAP) for outdoor mass cultivation of microalgae and cyanobacteria. Bioresour Technol 1991;38:153-9.

[25] Behrens P, Bingham S, Hoeksema S, Cohoon D, Cox J. Studies on the incorporation of $\mathrm{CO}_{2}$ into starch by Chlorella vulgaris. J Appl Phycol 1989;1:123-30.

[26] Richardson B, Orcutt DM, Schwertner HA, Martinez Cara L, Wickline Hazel E. Effects of nitrogen limitation on the growth and composition of unicellular algae in continuous culture. Appl Microbiol 1969;18:245-50.

[27] Rodolfi L, Zittelli GC, Bassi N, Padovani G, Biondi N, Bonini G, et al. Microalgae for oil: strain selection, induction of lipid synthesis and outdoor mass cultivation in a low-cost photobioreactor. Biotechnol Bioeng 2009;102:100-12. 